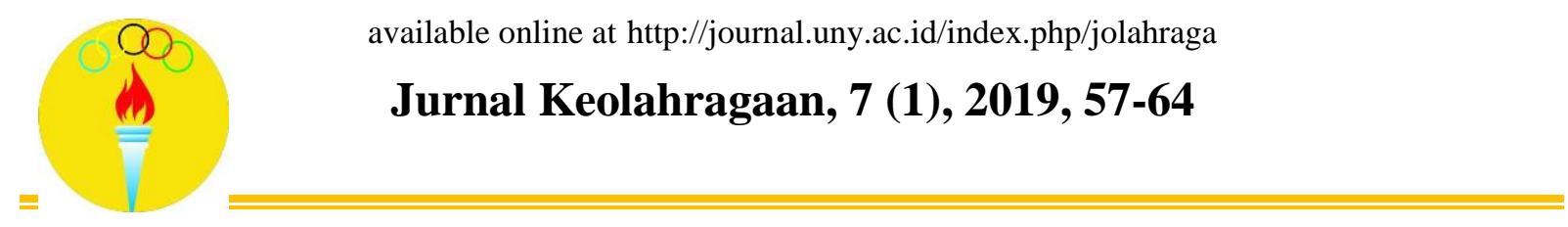

\title{
Baseball and biomechanics: Injury prevention for baseball pitcher
}

\author{
Fajar Awang Irawan ${ }^{1 *}$, Chuang Long-Ren ${ }^{2}$ \\ ${ }^{1}$ Department of Sport Science, Faculty of Sport Science, Universitas Negeri Semarang \\ Sekaran, Kecamatan Gunungpati, Kota Semarang, Jawa Tengah 50229, Indonesia \\ ${ }^{2}$ Sport Coaching Science, Chinese Culture University. \\ 55, Hwa-Kang Road, Yang-Ming-Shan, Taipei, 11114 Taiwan (R.O.C). \\ * Corresponding Author. E-mail: fajarawang@mail.unnes.ac.id \\ Received: 27 April 2019; Revised: 30 July 2019; Accepted: 1 August 2019
}

\begin{abstract}
Pitching was the fastest motion in baseball. Upper extremity has important roles especially in shoulder, elbow, wrist, and fingers. The purpose of this study was to integrate the information in a resume of biomechanical pitching and baseball pitcher's injuries. The data base used refers to PubMed, SAGE, and Elsevier and several relevance journals related to baseball and injuries. Source refers to the data since December 2017 to the oldest 2000 to get data source in baseball pitcher injuries. Upper arm has the prominent role when pitching to get maximum motion and joints stabilize. Rotator cuff muscle generate rotation in the shoulder while pitching and control shoulder joints in the lower arm's muscles and joints. Baseball pitcher has a special skill in the strength, speed, and endurance. They had to keep their performance to avoid from injury especially shoulder and elbow injuries. Biomechanical analysis can help to evaluated performance in monitoring dan give recommendation to elevate skills and prevent injury. Knowledge and understanding about basic of pitching have to mastering before elevate to the next level. Further study can focus on the time for the pitcher to improve the skills and maximizing the pitch type to avoid from injuries.
\end{abstract}

Keywords: injury, baseball pitcher, sport biomechanics

How to Cite: Irawan, F.A., \& Long-Ren, C. (2019). Baseball and biomechanics: Injury prevention for baseball pitcher. Jurnal Keolahragaan, 7(1), 57-64. doi:https://doi.org/10.21831/jk.v7i1.24636

do https://doi.org/10.21831/jk.v7i1.24636

\section{INTRODUCTION}

Baseball was a team game that popular in The United State, South Korea, Japan, Taiwan, and spread to Cuba, Philippines, and also in Indonesia. Based on Irawan (2019) popularization of baseball cannot be separated from softball that the modification of baseball itself. Indonesia has a popular traditional game with the name Kasti (Irawan, 2018) that similar to softball and baseball. Baseball game needs a lot of energy to consume, because not only using skills in throwing, hitting, and running but also should have endurance on going the game. A pitcher should have criteria such as strength, speed, and accuracy in throwing. Hirashima, Kudo, Watarai, \& Ohtsuki (2007) stated that pitching speed influenced by upper extremity of the baseball pitcher.

Throwing motion on pitcher was very fast in the game. Upper extremity has an important part in the pitching motion, especially in the arm, shoulder, elbow, wrist, and fingers. These body parts were very vulnerable to injury risk. The injury occurred because of an error in the movement, overtraining, and the number of throwing. Biomechanical analysis by G. S. Fleisig et al. (2011) found that pitcher who threw more than 100 per inning in one year significantly increased the risk of injury. It was strengthening that mechanism in pitcher's throwing has a high risk to the injury happened (Whiteley, 2007).

Basically, young pitchers trained to remain consistent in pitching on just one pitching type such as fastball. Increased pitching ability to the next level was not recommended as long as the pitcher has not been able to strengthen the main muscles that were possessed and throws the correct movements according to the recommended biomechanical analysis. The main focus was to keep giving attention to the pitcher not to use or try to pitch the ball using a curveball, slider or down-ball pitching type. This review was followed up on the study by Irawan \& Long-Ren (2015a) related to the biomechanics of pitching and preventing injuries to young pitchers. In the discussion, there were three important parts that 
cause injuries to the baseball Pitchers including accidents, overtraining, and errors in the biomechanics of throwing by the pitcher itself.

This article tried to explain kinetic, kinematic, and injury related to throws carried out by baseball pitchers. The purpose of this study was to integrated information in a summary of the biomechanics of pitching by baseball pitchers related to injuries sustained while pitching a ball. Recommendations would be presented to baseball pitchers to avoid the danger of injury suffered and also the way of healing of baseball pitchers who suffered injuries.

\section{METHOD}

The electronic database used refers to PubMed, SAGE, Elsevier and several relevant journals to be used as references. The sources refer to the data obtained in December 2017 back to the earliest available time 2000 to get one common source of biomechanics and injuries of baseball pitchers. Titles and abstracts in publication journals were screened to get relevant contents of articles to the themes and problems revealed in this article. Keywords used to obtain data such as injury, baseball pitcher, and sports biomechanics.

Twenty-six journal articles and two references book were used to be a data source in this study. Six articles were used as primer data refer to young pitcher, high school pitcher, and college pitcher and discussed injury of the pitcher, a suggestion for a young pitcher when they pitch in the competition, and injury prevention. Besides, research data in articles refer to the laboratory research and annual reports in baseball clubs. Supporting references were used as additional information in providing recommendations for injury prevention and performance improvement. The articles used were a complete report of the annual evaluation and laboratory experimental research that relevant to be a reference in this study.

\section{RESULT AND DISCUSSION}

Data obtained based on the study by G. S. Fleisig et al. (2006) stated that young pitchers who threw more than 100 times at one innings in a year had an increased risk of injury before pitcher elevates to the next level. The advice given to the young pitchers before the age of 13 was not to pitch curveballs for safety. Information about young pitchers was also explained by Harada et al. (2010) that the pitcher has a risk of injury 4.5 times higher than the players in other positions. Injuries that occur on softball and baseball pitchers were balanced on pitchers in high school level which was $81 \%$ of injuries were on the shoulders, and the other $10 \%$ of athletes must undergo surgery to heal the injury (Krajnik, Fogarty, Yard, \& Comstock, 2010).

Related to injuries that occur in young pitchers, study by Dun, Loftice, Fleisig, Kingsley, \& Andrews (2008) stated that curveball did not have the potential for more severe injuries when compared to fastball, it also related to the study by Solomito, Garibay, Õunuu, Tate, \& Nissen (2013) that breaking pitches such as curveballs and sliders were not dangerous. Based on Irawan, Chuang, \& Peng (2017) in laboratory research found that fastball still had a higher risk of injury when compared to curveball and slider pitch types.

\section{Pitching Mechanism}

The mechanism of pitching in baseball can be divided into six phases. The phases of pitching which were: wind-up, stride, arm cocking, acceleration, deceleration, and follow-through. According to Oyama et al. (2013) phases in arm cocking, acceleration, and deceleration were the phases that have more emphasis on the arm when pitching. This statement can be the reason why the injury happened.

\section{Pitching Phases}

When pitching made, the pitcher must go through in the several correct stages, the movements made can help to maximize perform in the pitching results and prevent from injuries. According to Irawan et al. (2017) described in Figure 1, every pitching phase carried out by pitchers has an important role in the effectiveness of the movements displayed. Every single step should be focused and studied carefully to be able to produce effective pitching. The first step was carried out to focusing on the wind-up phase, which was the body of pitcher positions the body with starting position towards the front with a focus on the catcher position. This phase ranges from 0.5 to 1.0 seconds.

The study from Irawan \& Long-Ren (2015a) about pitching phases time based on Braatz \& Gogia (1987) found that the time taken in this phase was around 1.3 seconds. The second phase was stride or stepping, this movement was performed in a sideways position and facing towards the catcher. The footsteps in stride length were kept low during the step forward and the 
shoulders stay parallel to provide body balance of the pitcher. The stride length was around $80-90 \%$ of the body height, and some pitchers prefer to extend their steps to get closer to the target and stabilize the movement during the pitching process.

The cocking phase was when the shoulder abducted and external lateral rotation was characterized by the released of the ball from the glove and ends when the maximum external rotation. In the beginning, the shoulder acceleration phase was in a complete external rotation position and there was a horizontal anterior abduction in the capsule joint tissue. After the acceleration phase was complete, the deceleration phase was only a hundredth in second (Rizio \& Uribe, 2001) to transfer the energy and not to influence the ball in emphasis or to spin. The last phase was the follow-through, this phase plays after the ball was detached from the finger and was divided into the beginning and the end of the phases when using the maximum rotation of the humerus as a marker of the movement was still running. A brief explanation can be seen in Figure 1 about the series of movements when the baseball pitcher throws the ball.

In the literacy explanation that the previous studies (Irawan, Chuang, Peng, \& Huang, 2016; Irawan \& Long-Ren, 2015b) provide additional information to further clarify the understanding in effective movements and how to avoid injury as fast as possible.

\section{Injuries on Baseball Pitcher}

Overtraining on a baseball pitcher can increase fatigue in muscles, tendons, and ultimately damage to the ligaments. To control some of the injuries encountered requires collaboration between several experts such as physiotherapy, coaches, athletes, best friend, the environment and also family to understand more complete information especially about anatomy, biomechanics, training programs and basic weight training techniques when training on a baseball pitchers (Irawan et al., 2016; Irawan \& LongRen, 2015a; Shitara et al., 2017).

The injuries that often occur in baseball pitchers were the shoulder and elbow. Diagnosis and checking of shoulder pain need to be given more attention related to conditions that may become more severe. Pathological conditions that cause injury and dysfunction in motion especially on the shoulder and elbow were the main concerns. Keeley, Oliver, \& Dougherty, (2012) stated that during arm cocking and acceleration, the elbow was the most vital part for tremendous valgus and excessive extension.

The discussion for shoulder injuries which was often a serious concern was the risk of dislocation from tendon extending due to overtraining. As for the shoulder, serious injuries concern at the risk of dislocation from stretching of the tendon due to overtraining. Shoulder injury according to Olsen, Fleisig, Dun, Loftice, \& Andrews, (2006) related to the stability of the shoulder itself, the injury was divided into unilateral and multidirectional instability. Unilateral injuries were usually traumatic from injuries that were natural in happened and occur on their own due to the repetition of motion. For example, injuries to the shoulder during abduction and external rotation which causes anterior dislocation. It was different from the axillary nerve which was an injury and often occurs in dislocations at the anterior shoulder. Multidirectional injuries usually would not cause trauma but because this injury was caused by overtraining (Kocher, Waters, \& Micheli, 2000). The risk of injury such as pain in the elbow of a young baseball pitcher was related to the number of pitches in each competition and the number of times a competition participated in each season. A young pitcher who throws more than 85 times per game, more than eight months a year, and with arm fatigue for several times even indicated that a recurring injury indicates to get surgery on the elbow. That was also confirmed by Fleisig, Chu, Weber, \& Andrews, (2009) which stated that weak pitching mechanics contributed more to the risk of injury.

Four factors that had a risk of pitchers injury have been identified in the research laboratory by Petty, Andrews, Fleisig, \& Cain, (2004) for baseball pitchers, included: the number of throws taken during the game, one season, and one year; the type of pitches, such as curveball, slider, or knuckle (breaking pitch type); pitching mechanics, and; the physical condition of the pitcher.

\section{Injury Prevention on Baseball Pitcher}

Knowledge and information about injury risk and the correct pitching techniques were basic knowledge in understanding the technique of pitching at baseball pitchers. Based on Axe, Windley, \& Snyder-Mackler (2002) stated that education and knowledge about prevention were the two main concepts that must be possessed by a pitcher to avoid injury in playing baseball. Related information was also stated by (Irawan et 
al., 2016; Irawan \& Long-Ren, 2015a, 2015b) that in understanding the linkages of each injury in sports, prevention was the best way to cure it. The best way to prevent injury was to keep our body protected from injury or symptoms that indicated to the injury. This entry applied to all activities and sports that were carried out.

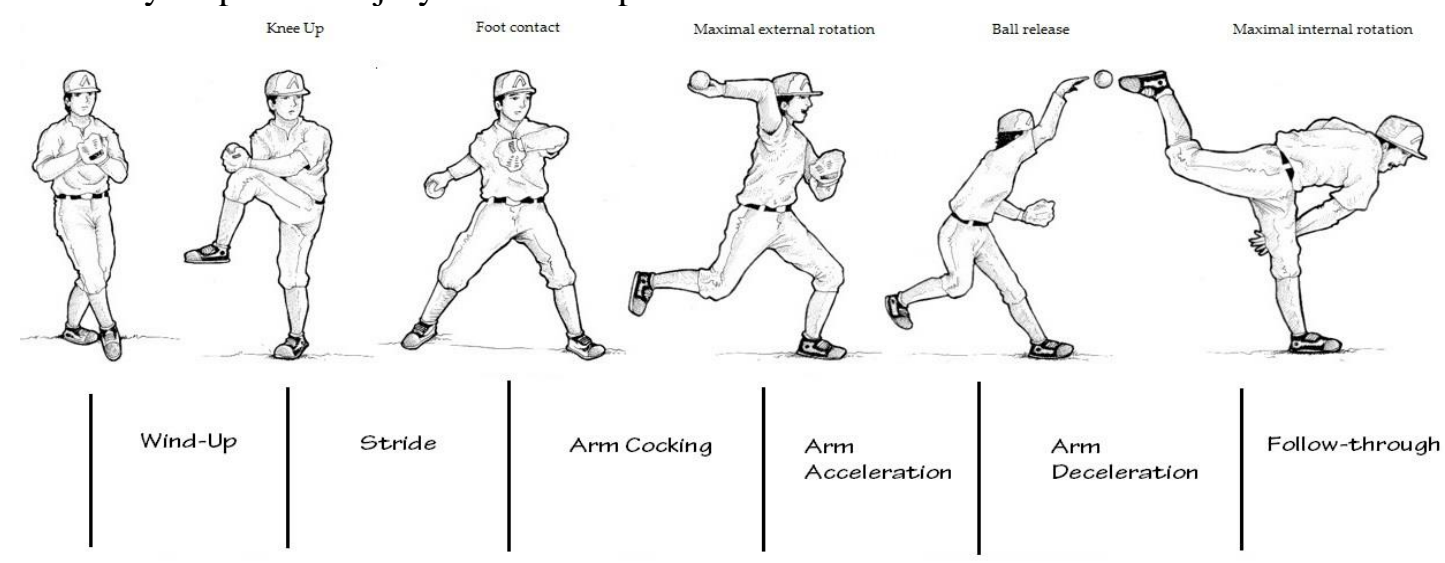

Figure 1. Pitching Phases in Baseball

Table 1. Biomechanical Analysis of Baseball Pitcher Injuries

\begin{tabular}{|c|c|c|c|c|c|c|c|}
\hline Period & Level & Method & Discussion & $\begin{array}{l}\text { Elbow } \\
\text { Injury }\end{array}$ & $\begin{array}{l}\text { Shoulder } \\
\text { Injury }\end{array}$ & Conclusion & Author \\
\hline $\begin{array}{l}1999- \\
2008\end{array}$ & $\begin{array}{l}\text { Young } \\
\text { Pitcher }\end{array}$ & Annual Survey & $\begin{array}{l}\text { Pitching more } \\
\text { than } 100 \text { per } \\
\text { Inning in a year }\end{array}$ & $\begin{array}{l}\text { Curveball has } \\
\text { less proximal } \\
\text { than fastball }\end{array}$ & $\begin{array}{l}\text { Curveball } \\
\text { produces lower } \\
\text { adduction } \\
\text { torque that } \\
\text { Slider }\end{array}$ & $\begin{array}{l}\text { Pitcher before } 13 \\
\text { years old were } \\
\text { not allowed to } \\
\text { pitch Curveball }\end{array}$ & $\begin{array}{l}\text { (G. S. Fleisig } \\
\text { et al., 2006) }\end{array}$ \\
\hline $\begin{array}{l}2001- \\
2006\end{array}$ & $\begin{array}{l}\text { Young } \\
\text { Pitcher }\end{array}$ & $\begin{array}{l}\text { Laboratory } \\
\text { Research }\end{array}$ & $\begin{array}{l}\text { Pitcher has } 4.5 \\
\text { times higher risk } \\
\text { of elbow injury } \\
\text { than another } \\
\text { player position }\end{array}$ & $\begin{array}{l}\text { Risk factor of } \\
\text { elbow injury } \\
\text { include age, } \\
\text { height, } \\
\text { duration of } \\
\text { exercise, grip } \\
\text { strength, } \\
\text { ROM, and } \\
\text { shoulder } \\
\text { muscle } \\
\text { strength }\end{array}$ & - & $\begin{array}{l}\text { Decreased } \\
\text { external } \\
\text { rotational ROM } \\
\text { on the shoulder } \\
\text { and increased } \\
\text { external } \\
\text { rotational } \\
\text { muscle strength } \\
\text { cause elbow } \\
\text { injury }\end{array}$ & $\begin{array}{l}\text { (Harada et al., } \\
\text { 2010) }\end{array}$ \\
\hline $\begin{array}{l}2005- \\
2008\end{array}$ & $\begin{array}{c}\text { High } \\
\text { School } \\
\text { Pitcher }\end{array}$ & $\begin{array}{c}\text { On-line } \\
\text { Information } \\
\text { Report }\end{array}$ & $\begin{array}{l}\text { Similarity in } \\
\text { shoulder injuries } \\
\text { on softball and } \\
\text { baseball }\end{array}$ & - & $\begin{array}{l}81 \% \text { of } \\
\text { shoulder } \\
\text { injuries and } \\
10 \% \text { athletes } \\
\text { had surgery } \\
\end{array}$ & $\begin{array}{l}\text { The average and } \\
\text { injury pattern in } \\
\text { different players } \\
\text { position }\end{array}$ & $\begin{array}{l}\text { (Krajnik et al., } \\
2010 \text { ) }\end{array}$ \\
\hline $\begin{array}{l}2007- \\
2008\end{array}$ & $\begin{array}{l}\text { Young } \\
\text { Pitcher }\end{array}$ & $\begin{array}{l}\text { Laboratory } \\
\text { Research }\end{array}$ & - & $\begin{array}{l}\text { Varus torque } \\
\text { and proximal } \\
\text { on the elbow } \\
\text { produce high } \\
\text { value on } \\
\text { curveball }\end{array}$ & $\begin{array}{l}\text { Horizontal } \\
\text { adduction and } \\
\text { shoulder } \\
\text { torque } \\
\text { adduction were } \\
\text { smaller at } \\
\text { change-up }\end{array}$ & $\begin{array}{l}\text { Curveball has no } \\
\text { potential for } \\
\text { serious injury } \\
\text { compared to } \\
\text { fastball }\end{array}$ & $\begin{array}{l}\text { (Dun et al., } \\
2008 \text { ) }\end{array}$ \\
\hline $\begin{array}{l}2012- \\
2013\end{array}$ & $\begin{array}{l}\text { College } \\
\text { Pitcher }\end{array}$ & $\begin{array}{l}\text { Laboratory } \\
\text { Research }\end{array}$ & $\begin{array}{l}\text { Breaking pitch } \\
\text { may not be the } \\
\text { cause of injury } \\
\text { on student } \\
\text { pitcher }\end{array}$ & $\begin{array}{l}\text { Fastball and } \\
\text { other types of } \\
\text { breaking } \\
\text { pitches were } \\
\text { important for } \\
\text { shoulder and } \\
\text { elbow joints }\end{array}$ & - & $\begin{array}{l}\text { Breaking pitch } \\
\text { were not the } \\
\text { most dangerous } \\
\text { pitch type for } \\
\text { student pitcher }\end{array}$ & $\begin{array}{l}\text { (Solomito et } \\
\text { al., 2013) }\end{array}$ \\
\hline $\begin{array}{l}2016- \\
2017\end{array}$ & $\begin{array}{l}\text { College } \\
\text { Pitcher }\end{array}$ & $\begin{array}{l}\text { Laboratory } \\
\text { Research }\end{array}$ & $\begin{array}{l}\text { Comparison } \\
\text { among fastball, } \\
\text { curve, and slider }\end{array}$ & $\begin{array}{l}\text { Elbow torque } \\
\text { was higher } \\
\text { than slider }\end{array}$ & $\begin{array}{l}\text { Shoulder } \\
\text { torque on } \\
\text { fastball was } \\
\text { higher than } \\
\text { curveball }\end{array}$ & $\begin{array}{l}\text { Fastball has } \\
\text { more injury risk } \\
\text { compared to } \\
\text { curveball and } \\
\text { slider }\end{array}$ & $\begin{array}{l}\text { (Irawan et al., } \\
\text { 2017) }\end{array}$ \\
\hline
\end{tabular}


Elbow injuries to the athletes who have special features in pitching were the result of biomechanics in the strength to the elbow during the throwing motion. Isolated soft tissue and bone injuries to the joints often occur in athletes who often used pitching motion in baseball. To minimise injury, baseball pitchers must increase and prepared their body parts from tension or unpreparedness when pitching. G. S. Fleisig \& Andrews (2012) stated that young pitchers were not encouraged to advance to the next level before mastering the basic techniques of correct pitching on the basic pitching (fastball). It based on the main foundation in the fastball pitch that the straight throw towards to the catcher must be at maximum speed and supported by the strength of muscles and joints that coordinate with each other so that collaboration occurs in a series of movements that would produce the correct and accurate pitching.

Under the rules and guidelines for the Major League Baseball in United States of America in 2006 stated by Fazarale, Magnussen, Pedroza, \& Kaeding (2012); Irawan \& Long-Ren (2015a) that young pitchers at 13 to 14 years old can only pitch 75 times per game and for the regulation of Little Leagues Baseball in 2010 that young pitchers can only pitch 95 times per day. Whereas pitchers who were 17 to 18 years old could only pitch 105 times per day. Fazarale et al. (2012) added the information to the pitchers who were 13 to 18 years old that they could pitch 100 times in combination every year per inning and at least within four months with 2 to 3 months continuously.

National Athletic Trainers' Association gave recommendation related to the limit of pitching to reduce the number of injury on baseball pitching (Fazarale et al., 2012). The recommendation was; pitcher with 9 to 14 years old have limited the number of pitching 75 times in one competition, 600 times in one season, 2000 to 3000 pitches per year. Pitcher 15 to 18 years old suggested not to pitch more than 90 times per game, and no more than two games in one week. Review of Sports Biomechanics

When the whole body was doing pitching, the emphasis would be on the upper arm to the fingers. Upper arm muscles had an important role when pitching to produced maximum movement and stabilized the joints, especially in the shoulder joints. The rotator cuff muscles play an important role in rotating the shoulders during pitching and provide dynamic stability to the shoulder joints to support the pitching move- ments of the muscles and joints in the lower arm. This study was consistent with the reference study by Irawan \& Long-Ren (2015b) that shoulder injuries have a relationship to the shoulder stability which was the shoulder itself was divided into unilateral and multidirectional instability. The explanations of unilateral injuries usually occur naturally, and some occur in the anterior body part around $90 \%$ to $95 \%$ and in posterior 5\% occur in dislocations. Multidirectional instability according to Irawan \& Long-Ren (2015b) was inversely proportional to unilateral injury, which was injury not a type of trauma but rather occurs due to overuse.

Clements, Ginn, \& Henley (2001) added information when the elbow extends $20^{\circ}$ during ball release makes the elbow extension unpredictable according to the movement when pitching because it adjusts the movement during follow-through as a further movement and minimises the injury pitching. This reason was also strengthened by the angular velocity of the elbow when maximising its existence by integrating the upper extremity in clockwise rotation (Naito, Takagi, Yamada, Hashimoto, \& Maruyama, 2014).

Krajnik et al. (2010) reported that baseball pitchers accounted for the largest proportion of shoulder injuries by $38 \%$. Whereas the data for softball reported for pitchers was $15 \%$, first base position $15 \%$, and catchers $15 \%$ in shoulder injuries. The motion of the baseball pitcher focused on the amount of emphasis on the rotator cuff during the deceleration phase. This incident represented that baseball pitchers used arm rounds faster during a career as a pitcher.

The shoulder injury was more common in the arm cocking phase. Pitchers experience pain and even feel pain in the medial elbow during the end of the arm cocking phase or at the beginning of the arm acceleration phase. Initial diagnosis of injury that begins with pain found in the ligaments on the ulnar collateral, physiologically can be felt and seen inflammation in the posterior and distal with pain or hurt that makes the injury to the flexor tendon along the pathway of the anterior ulnar ligament (Cain, Dugas, Wolf, \& Andrews, 2003).

The results obtained from several references provide information to the author to provide recommendations, especially to beginner baseball pitchers to keep focused on making the correct movement before the next stage. Knowledge of the correct pitching technique using biomechanical analysis could help to provide and 
evaluate the appearance pitching performance, gradual supervision and the existence of important annual records that serve as a reference would be meaningful and useful for the development and improvement of pitchers performance.

\section{CONCLUSION}

Baseball pitchers need more ability on strength, speed, and accuracy. A pitcher should be able to maintain performance to avoid injuries suffered, especially on shoulder and elbow. Understanding and knowledge of basic pitching techniques should be mastered correctly so the pitchers can increase their ability to the next level and also could using pitching variations when competing in the championship. Future research is expected to be able to learn about how long the pitcher uses to be able to master and what types of variation variations can be used to avoid injury at the next level. Future studies were expected to discuss the time needed by pitchers to mastering pitching variation without experiencing an injury.

\section{REFERENCE}

Axe, M. J., Windley, T. C., \& Snyder-Mackler, L. (2002). Data-based interval throwing programs for collegiate softball players. Journal of Athletic Training, 37(2), 194203.

Braatz, J. H., \& Gogia, P. P. (1987). The mechanics of pitching. Journal of Orthopaedic \& Sports Physical Therapy, 9(2), $56-69$. https://doi.org/10.2519/jospt.1987.9.2.56

Cain, E. L., Dugas, J. R., Wolf, R. S., \& Andrews, J. R. (2003). Elbow injuries in throwing athletes: a current concepts review. The American Journal of Sports Medicine, 31(4), 621-635. https://doi.org/10.1177/036354650303100 42601

Clements, A. S., Ginn, K. A., \& Henley, E. (2001). Correlation between muscle strength and throwing speed in adolescent baseball players. Physical Therapy in Sport, 2(3), 123-131. https://doi.org/10.1054/PTSP.2000.0025

Dun, S., Loftice, J. W., Fleisig, G. S., Kingsley, D. S., \& Andrews, J. R. (2008). A biomechanical comparison of youth baseball pitches: is the curveball potentially harmful? The American Journal of Sports Medicine, 36(4), 686-
692.

https://doi.org/10.1177/036354650731007 4

Fazarale, J. J., Magnussen, R. A., Pedroza, A. D., \& Kaeding, C. C. (2012). Knowledge of and compliance with pitch count recommendations: A survey of youth baseball coaches. Sports Health: A Multidisciplinary Approach, 4(3), 202204.

https://doi.org/10.1177/194173811143563 2

Fleisig, G., Chu, Y., Weber, A., \& Andrews, J. (2009). Variability in baseball pitching biomechanics among various levels of competition. Sports Biomechanics, 8(1), $10-21$.

https://doi.org/10.1080/147631408026299 58

Fleisig, G. S., \& Andrews, J. R. (2012). Prevention of elbow injuries in youth baseball pitchers. Sports Health: A Multidisciplinary Approach, 4(5), 419424.

https://doi.org/10.1177/194173811245482 8

Fleisig, G. S., Andrews, J. R., Cutter, G. R., Weber, A., Loftice, J., McMichael, C., ... Lyman, S. (2011). Risk of serious injury for young baseball pitchers: A 10-year prospective study. The American Journal of Sports Medicine, 39(2), 253-257. https://doi.org/10.1177/036354651038422 4

Fleisig, G. S., Kingsley, D. S., Loftice, J. W., Dinnen, K. P., Ranganathan, R., Dun, S., ... Andrews, J. R. (2006). Kinetic comparison among the fastball, curveball, change-up, and slider in collegiate baseball pitchers. The American Journal of Sports Medicine, 34(3), 423-430. https://doi.org/10.1177/036354650528043 1

Harada, M., Takahara, M., Mura, N., Sasaki, J., Ito, T., \& Ogino, T. (2010). Risk factors for elbow injuries among young baseball players. Journal of Shoulder and Elbow Surgery, 19(4), 502-507. https://doi.org/10.1016/j.jse.2009.10.022

Hirashima, M., Kudo, K., Watarai, K., \& Ohtsuki, T. (2007). Control of 3D limb dynamics in unconstrained overarm 
throws of different speeds performed by skilled baseball players. Journal of Neurophysiology, 97(1), 680-691. https://doi.org/10.1152/jn.00348.2006

Irawan, F. A. (2018). Permainan kasbols (1st ed.). Semarang: Cipta Prima Nusantara.

Irawan, F. A. (2019). Softball untuk semua. (D. F. W. Permana, Ed.) (1st ed.). Semarang: Fakultas Ilmu keolahragaan, Universitas Negeri Semarang.

Irawan, F. A., Chuang, L.-R., \& Peng, H. (2017). Kinematic comparison of upper extremity among fastball, curveball, and slider in Taiwan College Pitchers. Chinese Journal of Sport Biomechanics, 14(1), 1-8. https://doi.org/10.3966/207332672017061 401001

Irawan, F. A., Chuang, L.-R., Peng, H., \& Huang, S. (2016). A biomechanical baseball pitching: Is the curveball generating higher risk of injuries than fastball on young pitchers? Chinese Journal of Sport Biomechanics, 13(2), 55-63. Retrieved from

http://readopac2.ncl.edu.tw/nclserialFront /search/summny_list.jsp?sysId=00068981 $57 \& \mathrm{dtdId}=000040$

Irawan, F. A., \& Long-Ren, C. (2015a). Comprehensive pitching biomechanics and injury prevention for young baseball pitchers-a review. Journal of Physical Education and Sport Science, 21, 11-21.

Irawan, F. A., \& Long-Ren, C. (2015b). Pitching biomechanics and injury prevention to improving performance for young baseball pitchers - A review. In 1st UNNES International Conference on Research Innovation \& COmmercialization for Better Life. Semarang: Universitas Negeri Semarang.

Keeley, D. W., Oliver, G. D., \& Dougherty, C. P. (2012). A biomechanical model correlating shoulder kinetics to pain in young baseball pitchers. Journal of Human Kinetics, 34(1), 15-20. https://doi.org/10.2478/v10078-012-00598

Kocher, M. S., Waters, P. M., \& Micheli, L. J. (2000). Upper extremity injuries in the paediatric athlete. Sports Medicine, 30(2), 117-135. https://doi.org/10.2165/00007256200030020-00005

Krajnik, S., Fogarty, K. J., Yard, E. E., \& Comstock, R. D. (2010). Shoulder injuries in US High School baseball and softball athletes, 2005-2008. Pediatrics, 125(3), 497-501.

https://doi.org/10.1542/peds.107.4.782

Naito, K., Takagi, H., Yamada, N., Hashimoto, S., \& Maruyama, T. (2014). Intersegmental dynamics of 3D upper arm and forearm longitudinal axis rotations during baseball pitching. Human Movement Science, 38, 116-132. https://doi.org/10.1016/j.humov.2014.08.0 10

Olsen, S. J., Fleisig, G. S., Dun, S., Loftice, J. W., \& Andrews, J. R. (2006). Risk factors for shoulder and elbow injuries in adolescent baseball pitchers. The American Journal of Sports Medicine, 34(6), 905-912. https://doi.org/10.1177/036354650528418 8

Oyama, S., Yu, B., Blackburn, J. T., Padua, D. A., Li, L., \& Myers, J. B. (2013). Effect of excessive contralateral trunk tilt on pitching biomechanics and performance in high school baseball pitchers. The American Journal of Sports Medicine, 41(10), 2430-2438. https://doi.org/10.1177/036354651349654 7

Petty, D. H., Andrews, J. R., Fleisig, G. S., \& Cain, E. L. (2004). Ulnar collateral ligament reconstruction in high school baseball players: Clinical results and injury risk factors. The American Journal of Sports Medicine, 32(5), 1158-1164. https://doi.org/10.1177/036354650326216 6

Rizio, L., \& Uribe, J. W. (2001). Overuse injuries of the upper extremity in baseball. Clinics in Sports Medicine, 20(3), 453-468. https://doi.org/10.1016/S02785919(05)70262-3

Shitara, H., Kobayashi, T., Yamamoto, A., Shimoyama, D., Ichinose, T., Tajika, T., ... Takagishi, K. (2017). Prospective multifactorial analysis of preseason risk factors for shoulder and elbow injuries in high school baseball pitchers. Knee Surgery, Sports Traumatology, 
Jurnal Keolahragaan 7 (1), 2019 - 64

Fajar Awang Irawan, Chuang Long-Ren

Arthroscopy, 25(10), 3303-3310. https://doi.org/10.1007/s00167-015-37314

Solomito, M. J., Garibay, E. J., Õunpuu, S., Tate, J. P., \& Nissen, C. W. (2013). A biomechanical evaluation of the kinetics for multiple pitching techniques in College-Aged Pitchers. Orthopaedic Journal of Sports Medicine, 1(5), 1-8. https://doi.org/10.1177/232596711350825 5

Whiteley, R. (2007). Baseball throwing mechanics as they relate to pathology and performance - A review. Journal of Sports Science and Medicine, 6(1), 1-20. Retrieved from https://www.jssm.org/hfabst.php?id=jssm -06-1.xml 